https://helda.helsinki.fi

Fear and Anxiety : The Nationalist and Racist Politics of Fantasy

Hirvonen, Ari Juhani

2017

Hirvonen , A J 2017 , ' Fear and Anxiety : The Nationalist and Racist Politics of Fantasy ' , Law and Critique , vol. 28 , no. 3 , pp. 249-265 . https://doi.org/10.1007/s10978-017-9210-y

http://hdl.handle.net/10138/298253

https://doi.org/10.1007/s10978-017-9210-y

acceptedVersion

Downloaded from Helda, University of Helsinki institutional repository.

This is an electronic reprint of the original article.

This reprint may differ from the original in pagination and typographic detail.

Please cite the original version. 
Post-print. Ari Hirvonen: Fear and Anxiety. The Nationalist and Racist Politics of Fantasy. Law \& Critique Nr. 3, Vol. 28, 2017, 249-265.

\section{FEAR AND ANXIETY. THE NATIONALIST AND RACIST POLITICS OF FANTASY}

\section{ARI HIRVONEN}

Faculty of Law

University of Helsinki

Finland.

Email: Ari.Hirvonen@helsinki.fi

ABSTRACT. Crises have become a new normality. This normality is turned into grounds for the politics of fear. The hegemonic principle of the politics of fear is security. This politics, which invents objects of fear, is intimately linked to the nationalist identity politics shaped by a particular nationalist essence. Racism is an elemental part of the nationalist identity politics. In the text, racism is considered in relation to, on the one hand, fear and anxiety and, on the other hand, the imaginary and symbolic orders and the structure of fantasy. This analysis shows how xenophobic images, nationalist signifiers and racist fantasies create the vicious circles of fear and hate that gives justification for the nationalist identity politics that raises security as the hegemonic organizing principle. To counter the nationalist identity politics, the 
nationalist and racist fantasy must be traversed. Therefore, an anti-racist politics cannot be based on any pre-given identity. It takes place only as emancipatory events that confront the racists and nationalist fantasy.

KEYWORDS. Anti-racism, anxiety, fantasy, Lacan, nationalism, psychoanalysis, racism, xenophobia.

\section{Urgent fears}

In late November 2015, a-graffiti - L'état d'üúrgence pour faire oublier les tas d'urgences - appeared on the north bank of the Seine. The graffiti, which proclaimed that the state of emergency is used to cover heaps of emergencies, criticized the state of emergency that was declared immediately after the terrorist attacks around Paris. Even if the nationwide state of emergency was justified immediately after the brutal terrorist attacks, it has been prolonged six consecutive times by the Parliament. As of July 2017, it has been the longest uninterrupted state of emergency since the Algerian war.

The graffiti claims that the fight against terrorism turns attention away from urgent issues, such as climate change, unemployment, inequality and racism. The threat of terrorist attacks has led to excessive and disproportionate restrictions on fundamental rights. The extraordinary measures and control practices violate the prohibition against ethnic profiling. A majority of those who are held under house arrest and whose homes are raided are French Muslims. Not just religious fanatics or migrants from designated high-risk countries and suburban Arab young men, but all members of the Muslim population have been considered potential threats. Individual behaviour and guilt are no more crucial. More important is to which group an individual belongs and what kind 
of potential risks his background and behaviour indicates. 'The intervention constitutes an administrative measure based on a general assessment of risk' (Hörnqvist 2004, p. $38)$.

The French exception is not exceptional. In contemporary societies, onea crisis is followed by another-one: from terror attacks to environmental disasters, from economic to ecological crises, from the crisis of human displacement to the sovereign debt crisis, from the democracy deficit to the-Brexit. According to Jacques Rancière, the concept crisis, which used to refer to the moment of the resolution of disease, has become the description of the state of things that allows 'drastic measures to be taken' (Rancière 2013, p. 20). Crises have become a new normality and this normality is turned into grounds for the politics of fear. The hegemonic principle of this politics is security. Its instrument is 'preventive justice which attacks anything that is sure, or at least likely, to trigger terror, anything that threatens the social bond holding the community together' (Rancière 2009, p. 114). According to Giorgio Agamben, 'politics secretly works toward the production of emergencies' (Agamben 2002). The difference between legal order and security policy, law enforcement and security services, police and military, judiciary and administration are eroded step by step. Moreover, the state of emergency and other crisis situation instruments are gradually incorporated into the law so that it would be more effective in providing security. French President ${ }_{2}$ Emmanuel Macron $_{2}$ has said that the government wants to lift the state of emergency towards the end of 2017. However, the government is drafting a new anti-terror security law, which would integrate several of the state of emergency powers permanently into the law (Bamat 2017). The new law would normalize the state of exception. According to Magnus Hörnqvist, 'systematic abuses are not questioned precisely because they have been systematized' (Hörnqvist 2004, p. 49). The division between law and fact, 
normativity and factuality is suppressed as the necessity and urgency of security has become the new supreme law that dictates politics turned into crisis management.

Besides, there is an extensive use of fear devised to highlight these crises. A basic constituent of contemporary subjectivity is fear. In the times of neoliberal management and regulation without politics, fear becomes the most effective way to introduce passion and mobilize people (Žižek 2008, p. 34). The combination of the security principle, preventive justice and crisis management justifies its logic - the ordinary legal instruments alone are 'not enough to provide security' (Altheide 2006, p. 416) - with the discourse of fear. There are no limits to these discourses that promote 'a sense of disorder and a belief that "things are out of control"' (Altheide 2006, p. 420). On the one hand, the discourse of fear invents potential risks and threats creating the images of fear. On the other hand, fear is derived from these threats and fearful disorders.

Local and global terrorism is the main area for recognizing the objects of risk, threat and fear. But the same logic functions in many other fields. For instance, the European political discourse around refugee policies is thick with crisis mentality, fear and loathing. The refugees are seen as a threat in terms of human, social and economic security. Europe has to protect its borders, since otherwise 'our societies will be totally destabilized' and 'the very idea of Europe... will be questioned' (Valls in Chrisafis et. al. 2016). This discourse of fear justifies anti-immigration laws and administrative and judicial practices that violate human rights, international refugee law and national migration legislation. The free circulation that is opened up by global capitalism concerns things, while the circulation of people - those objects of fear - has become more and more controlled so that 'the fundamental divide is between those included in the sphere of (relative) economic prosperity and those excluded from it' (Žižek 2004). 
When people define their situation as fearful and dangerous, their community and social life becomes more hostile, as David Altheide points out (Altheide 2006, p. 423). According to psychoanalyst ${ }_{2}$ Paul Verhaeghe, today the society focuses on the individual and there is a constant pressure for self-management. 'As a result, people feel less secure and more mistrustful of others. They are also much quicker to express aggression against any "other" they perceive as potentially threatening' (Verhaeghe 2014, p. 218). As refugees, migrants, Muslims, unemployed youngsters and the working class are considered the objects of fear, fear and loathing have become incorporated not only in the social relationships and minds of people but also in the state apparatus. Fear and loathing give the government free hands, 'because once the state has been occupied by fear, it can freely create fear' (Badiou 2008, p. 13). The creation of fear escalates as various phenomena - refugees, poverty, drugs, fundamentalism, anti-governmental demonstration, the Occupy movement - that are not really related are all are 'treated as security threats ... related to one another ... and, at the same time ..... tied firmly into the security problem par excellence: terrorism' (Hörnqvist 2004, p. 39).

The politics of fear is based on the discourse of fear that attaches the signifiers of fear, risk and threat to designated bodies, individuals and groups. This depoliticized politics has various forms and names: crisis management, preventive justice, antiimmigration policy, and war on terror.

As the discourse of fear invents the objects of fear ${ }_{2}$ it constructs individual and national identities. Hence, the discourse of fear, which is the ground of, or is translated into, the politics of fear, is intimately linked also to nationalist identity politics. ${ }^{1}$ Politics

\footnotetext{
${ }^{1}$ In this text, I speak of the racist identity politics, which must be kept separate from the progressive identity politics, which is committed to emancipation, liberation and equality and which asserts a
} 
is shaped by an already existing identity, which is held as the source of the affirmation of one's identity. The legal identity of the citizen and the global citizenship are too abstract and non-essential conceptions. The nationalist identity politics is shaped by an essence with which citizen-subjects identify. This politics relies on and refers to 'an unquestionable identity' (Žižek 2016), which 'is to be respected' (May 2010, p. 150). It takes responsibility for maintaining the national identity by reflecting, representing and fighting for and in the name of the essence of the national being. The national community appears as 'the corps of those with the same blood, ancestors, or identity' and thus the archaic power of birth is re-staged (Rancière 2004, p. 8). Common sense, traditions, religion, national values, native people, race, ethnicity, ancestral myths, soils and blood are fused together. At the same time, the essentialist national identity is exclusive. Others who do not share this common essence are marginalized or excluded. The process which identifies and presents people as threats to the national identity, the safety of society and its values is related to racism. Therefore, nationalism and racism are interconnected ${ }_{2}$ as opposed contrary to the argument of Benedict Anderson (Anderson 1993, p. 129). I use racism in a wide sense so that, in addition to a traditional race-related racism, it refers to all modalities of xenophobia (see Balibar and Wallerstein 1988).

The far-right nationalism leans on this kind of identity politics. On the one hand, the nationalist populism promises to preserve and cherish the integrity of the patrimony

particular identity against the unjust system to articulate experiences of oppression, exploitation and marginalization and brings particular subjects together. The progressive identity politics may also be based on strategic essentialism or non-essentialism. Even though I consider a political subject as the process of subjectivation in the interval between identities that participates universality, my critique is aimed exclusively at the racist identity politics. 
and the purity of national, cultural, religious and ethnic identity. On the other hand, it demands multi-cultural, -religious and -ethnical society to be rejected. It promises to halt or at least control immigration. Protectionism is an economic version of this nationalist identity politics. The fight for the preservation of the purity of national community and its shared way of life is combined with the critique of liberalism, established political parties and their arrogance in the face of the common people.

However, it is too easy to put the blame on the far-right nationalism. The surge of nationalist identity politics goes beyond the parties and electorate of the populist right. I will take up five points to show why.

First, the denunciation of far-right nationalist populism is used as a tactic to mask the rapid nationalist right-wing drift of European liberal-democratic political elites. The intertwined discourse and politics of fear in the EU is a new racism, a tendency 'to secure the isolation of the Union territory and thus to prevent the influx of immigrants' (Žižek 2004). There are 'growing levels of intolerance, racist hostility and hatred even in societies where equality and democracy have become enshrined ideals' (Hook 2007, p. 10; see Winnubst 2004; Clarke 2003).

Second, the far-right politics - together with its nationalist and anti-immigration attitudes and racist prejudices- is integrated into the prevailing political system (Rancière 2015). European liberal democrats do 'reject the open racism of antiimmigration populists', according to Slavoj Žižek, 'but at the same time profess that they "understand the concerns" of ordinary people, and so enact a more 'rational' antiimmigration policy’ (Žižek 2015a).

Third, by labelling undocumented migrants, Muslims, refugees and foreigners as enemies, threats and objects of fear, liberal-democratic governments are 'able to draw upon a powerful nationalist discourse' (Devetak 2004, p. 104). When the threat is 
manufactured it can be effectively defeated by deporting refugees and other objects of risk. Governments are able to reclaim control over their territory, borders and security - and the national identity. According to Alain Badiou, the European governments with their successive anti-immigration laws and policies, which attack freedom and equality of millions of people, have delivered over migrants as fodder to a disoriented and fearful electorate (Badiou 2012).

Fourth, the nationalist identity politics is introduced in the clothing of its opposite, universalism. The universalism of European values is manipulated and transformed into an instrument of distinction between 'us', the good Europeans representing liberty, equality, freedom and human rights, and 'them', the immigrants embodying Islamism, communalism, intolerance and sexism (see Rancière 2015).

Finally, one could blame the rise of nationalism on the neo-liberal socioeconomic model, 'a depoliticized technocracy in which bankers and other experts are allowed to demolish democracy' (Žižek 2012, p. 13), on the global capitalism that has transformed subjects into exchangeable commodities; or on the austerity policy and deregulated finance markets that has made unemployment and economic precariousness a permanent state. Due to these elitist technocratic policies, the feeling of powerlessness prevails. People are pushed in the search of stable identities and objects to which they could transfer their fears and insecurities.

As a consequence, racism is immanent in both the far-right populist and liberaldemocratic versions of nationalist identity politics. These politics are linked to the politics of fear and crisis management and justified by the double of the discourse of fear and the security principle. Racism may not be an explicit or conscious part of the nationalist identity politics. Often it is explicitly denied. However, racism seems to function at least as an unconscious element in the nationalist identity politics. 
To confront and counter the pathological discourse of fear and the nationalist identity politics - pathological because what motivates them are not facts but racist prejudices - it is not enough to bring forth the factual evidence that would convince

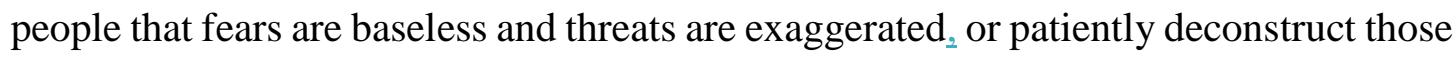
hierarchical binary oppositions that form the driving force of the nationalist identity politics. Therefore, I will consider the forms of embodiment of nationalism and racism from a psychoanalytic perspective. This perspective does not mean, as Derek Hook says, that the door would be opened to decontextualized psychological reductionism, which would isolate prejudices and racism as an individual psychopathology or as the faults of cognition of isolated subjects (Hook 2007, pp. 4, 10-12).

Racism as an elemental part of the nationalist identity politics ought to be considered not at the level of fear but in relation to anxiety. In psychology, nervousness is considered to be a feeling of uneasiness and disturbance that is located in experience and does not involve the body. If nervousness has to do with the body, this creates another order, anxiety. What the two have in common is the presumed absence of an object. What provokes nervousness or anxiety cannot be located. If one manages to locate the object, another order is reached, that is, fear (Harari 2001, p. 31). According to Sigmund Freud, fear - related to the instinct of self-preservation - seems to be rational and comprehensible as a reaction to the perception of external danger and threat. Unlike fear, anxiety takes place without specific objects. It is a 'free-floating fear ... which is ready ... to seize any opportunity to make itself felt' (Freud 1920). Persons who suffer from anxiety 'prophesy the most terrible of all possibilities, interpret every coincidence as an evil omen, and ascribe a dreadful meaning to all uncertainty' (Freud 1920). 
To answer what the mechanism that attaches fears to individual bodies and psyches, the affective components of anxiety, and the psychic structuring of nationalism and racism are, the nationalist identity politics and racism should be considered from three perspectives: the image, the signifier and the fantasy.

\section{RACIST IMAGES AND SIGNIFIERS}

I start with the image and the narcissistic ego formation. According to Jacques Lacan, at the mirror stage, the recognition of the self happens in the mirror image showing the illusory images which appears through concrete reflections and the reactions of the mother and others. The satisfactory image and perception of self takes the place of the fragmented and incoherent infant captivated now by these images. The price of apparent completeness and overcoming powerlessness is a fundamental alienation into the mirror image (Lacan 2006a, pp. 75-77).

The mirror stage is a structural position of the subject. The more anxious the subject is about losing her/his identity and control, the more fervently she/he holds on to her/his ideal ego. In the mirror, anxious, the subject is able to find solace in reflections of the subject who is supposed to be like her-/himself. Even if Lacan does not speak about race and racial identification as he considers the mirror stage, one can spot the roots of racism in the white mirror seen in Franz Fanon's Black Skin, White Mask.

For Fanon, there is another mirror, a racist mirror. Fanon describes the pathological function when a white ideal ego is encountered by black in the white mirror of identity. The white ideal reflects not the empowering fiction of power and unity but powerlessness and fragmentation. This reversed mirror stage that the black has to go through gives the black body 'back to me sprawled out, distorted, recolored' 
(Fanon 1986, p. 113; see also Kelly 2001, p. 33). Instead of reflecting agency, the mirror reflects threat. 'It was hate; I was hated, despised, detested', Fanon says (Fanon 1986, p. 118).

This pathological mirror has two functions. First, we - the true Germans, the good Finns, the natural-born English - see in the image of another what we are not. This other is an absolute other and as such excluded from our ego images. This process of inclusion/exclusion supports the ego formation. We are able to project our fragmentation, insecurities, identity crises, nervousness and anxiety onto this other. In relation to this figure of an excluded other we gain total identity based on stability and purity.

Secondly, Fanon tells of his experience of the imposition of a racialized identity on him. As he was confronted with a mother and a child, the child took fright at her sight of him: 'Mama, see the Negro! I'm frightened!' (Fanon 1986, p. 112). Fanon concludes, 'Now they were beginning to be afraid of me' (Fanon 1986, p. 112). At the same time as others are there for confirming our ego, they turn out to be threatening figures. This is the flip side of the 'jubilant assumption of [one's] specular image' (Lacan 2006a, p. 76). The child who saw Fanon was in no way in danger. Even if there was no concrete threat, a black figure or blackness itself aroused fear in the child. The mother did her best to calm the child down with rational words, but it did not help. The image of the black other is threatening for the girl. The black man is an intruder and even someone competing for the attention of the mother. The child projects her interior insecurities, fragilities and aggression onto the black other, an absolute outsider.

Next, the signifier. The symbolic order as an organizing principle and law is itself universal, but it has temporalized content. It is made of linguistic, social and cultural structures, networks and norms regulating signification. The infant is born into 
the symbolic. There is no pure imaginary identification. The infant is bound to its image by speech, words, sentences and names. Symbolic identification with a signifier frees the infant from being completely captivated by images. The pathological mirror is in relation to the symbolic order, and images are structured by language.

The racist nationalist imaginary logic does not function without the back-up of the pathologic signification and the acceptance of the symbolic father, which for $u s$ is the nation and its populist spokespersons. The contemporary Master Signifier is the nation. It - and other privileged signifiers such as 'secularity', 'fraternity', 'white', 'European' - function as an ordering principle that guarantees coherence to a society around which other signifiers are anchored. The 'nation' is, as Mladen Dolar says, 'a structural function that power gets hold of, but which is in itself empty, devoid of meaning, a pure positivization of a void' (Dolar 1999, p. 87). The nation functions like the signifier phallus, which is an empty signifier, though this does not mean that it would be without efficiency and effects. Due to these posited and prioritized empty signifiers, which we invest with devotion, the national community functions as if the Other as the symbolic order lacked nothing that would make it impossible to reach a complete and consistent totality. Negative signifiers such as 'terror', 'illegal migrant', 'Muslim', 'Roma' and 'black' get their value and meaning in relation to the Master Signifier and other privileged signifiers such as 'secularity', 'fraternity', 'white' and 'European'. We do not even have to believe in these signifiers. It is enough that we think that our fellow-beings believe in them.

\section{RACIST NATIONALIST FANTASY}


The imaginary and symbolic identification form images of narcissistic and homogenous we-egos versus them who are caught up in the signifying chains organized around hierarchical and exclusory anchoring points.

At the symbolic level, the infant gets an answer to the question of what the mother wants due to the paternal metaphor, the signification of the phallus. The answer to the question of desire at the symbolic level is not the final answer. In the mother's act, gaze and speech there is always something that the child cannot understand at the level of language.

As Lacan says, 'the Other's question [la question de l'Autre] - that comes back to the subject from the place from which he expects an oracular reply - which takes such form as "Chè vuoi?", "What do you want?", is the question that best leads the subject to the path of his own desire' (Lacan 2006b, p. 690). The existential question the subject confronts is: what am I for the Other? Since the subject does not know what the other wants from her/him, the subject feels anxiety. The fantasy comes to help by answering this anxiety-arousing question.

The subject manages to answer the fundamental question by inventing a fantasy which makes it possible for the subject to assume the identity of an object that has a privileged value in relation to the Other. This object is not a signifier circulating in the signifying chains but an object that is a left-over of the entrance to the symbolic order and symbolic identification. This remainder Lacan calls object $a$. The fantasy provides the system of formation and processing of these objects. The subject clings to the object in her/his fantasy which makes up for what is lacking in the subject. Thus, the fantasy does not refer to daily imagination, daydreams or imagined unrealities but to profounder unconscious fantasies. Instead of satisfying desire in an imaginary or hallucinatory way, the fantasy is what constitutes the desire. Everyone has to invent her or his own fantasy 
which is a formation in which the scopic plays an essential role. It is 'a signifying arrangement', which couples the barred subject and the presence of object $a$ (Lacan 1966-67). The fantasy is not merely a matter of the ego and imaginary body but more a matter of the subject. The fantasy is not "isolated on the terrain of the internal imaginary' (Harari 2001, p. 214). The racist nationalist fantasy is related to both pathological images and signifying chains. The fantasy is invited at the border of the imaginary and the real, but it is not without connection to the symbolic.

At the symbolic level we identify with the various signifiers of a nation. Our identity is floating in the signifying chains of the racist nationalist discourse anchored in the Master Signifier Nation: 'I am a true French/German/Italian'. However, as much as we confirm our identity, language does not provide $u s$ with a sufficiently proper identity. Even if the words are ours, they seem not to belong to us. Everyone uses them, even those others. There is something alienating in them. They belong to the lacking Other. Words, marks, symbols, signifiers fail to designate our being, to answer in a fundamental way who we are. Think about European citizenship, which is merely a symbolic-legal identity. The European Union has the flag and anthem, legislation and borders, common values and principles, elections and government, and discourses and symbols about being European. At the airport, there are two identical checkpoints. Nothing distinguishes these except the signifier above the gate: 'EU Citizens', above one; 'Non-EU Citizens', above another. I choose the first gate without further consideration since I identify with the signifier. All these EU signifiers do not really designate what one is. EU citizenship is a failure since it does not manage to answer the existential question about one's being. It does not guarantee any stable identity, and thus one clings to the national identity. This is what makes the contemporary nationalist identity politics so popular. 
The EU is not an aberration, but it reveals the truth of all nations. There is no guarantee of a harmonious nation and homogenous race in which one would have a proper place as a citizen, a patriot and a white body as a subject for other similar citizens, patriots and bodies. The nation, race and our identity in the closed national community must be screened through a nationalist fantasy. This is a precondition for the function of nationalism and racism. We - one by one-invent our own - at the same time shared - fantasy of one nation. Our common nation based on sameness is possible only inasmuch as we all adhere to it. This is a pathological fantasy about a perfect state, a stable and coherent subjective and national identity, where we come together in a pure community that we share as homogenous individuals ontologically and historically.

Chè vuoi? For the desire of others in our national community, we are similar, desired as a member of this homogenous community. Object $a$, the remainder from the alienation process of becoming a speaking being in a national community, becomes a foundation for our national identity, a compass for our life together in our nation. It is the breast of the nation, the voice of the people, the gaze of the leader, the excrement of others. This is what the French ultra-nationalist ${ }_{2}$ Charles Maurras ${ }_{2}$ once meant as he made a distinction between the legal country, the French Republic of secularism and formal laws run by functionaries, on the one hand, and the real country, a rural France of native people, traditions and church clocks, today embodied by Marine Le Pen, on the other (Kuper 2017). Fantasies nourish these nationalist identifications in a more fundamental and passionate way than symbolic identifications are able to do. This kind of nationalist fantasy is at the core of a racist nationalist being. At the level of the fantasy we find an answer to the existential question of who we are. The fantasy invents our nation as we perceive it. Our experience of the reality of the shared nation and our lives 
as part of it are regulated by the fantasy. The fantasy parcels out our positions and forms of participation at the same time as it produces self-evident facts.

The positive side of the fantasy promises full enjoyment as we become full members of the organic community without lack. It is a beatifying and stabilizing fantasy. We cling to the fantasmatic idea of a nation without disruption, differences and dissensus. We passionately cling to the full enjoyment these fantasies promise us. All the national myths, stories and fantasies nourish these fantasies.

In this racist nationalist fantasy various positions are possible. In the specular and immediate identification we identify with our imaginary ideal ego. Another possibility in the fantasy narrative is a position 'from which specular identification may be seen in a satisfactory light' (Lacan 2004, p. 268). In this situation, the imaginary identification is supported by the Other: the racist subject sees himself, 'as one says, as others see him' (Lacan 2004, p. 268). We see ourselves as the members of the nation from the point of love of our fellow citizens. The fantasy narrative introduces 'a perspective centered on the Ideal point, capital I, placed somewhere in the Other', from which the nation as a whole sees $u s$ in the form in which we like to be seen (Lacan 2004, p. 268). The nation loves $u s$ or, more precisely, loves in $u s$ something that is more than ourselves. It loves the object $a$ in $u s$. That is, we ourselves are actually the objects of the fantasy, since we take the position of object $a$, which offers a nationalist consistency to our lacking being. Object $a$, which is present in the drive, is the foundation of our identification but also 'the foundation of an identification disavowed' by $u s$, that is, the foreigner other (Lacan 2004, p. 186). At the same time, the nation sees $u s$, and we as spectators see our nation purifying and uniting itself into a total homogenous community before us. Our fantasy realizes the desire, which is, as said, 
not our desire but the Other's desire. We are answered with what the Other wants from $u s$.

The construction of the objects of fear at the imaginary and symbolic level is inadequate for the racist nationalists. It does not relieve them from the sense of something lacking in their life, being, body and community. Thus, the objects of fear have to be invented at the fantasy level. And since what we really enjoy has no true positive attributes, we need another side of the fantasy. This is related to the other side - racism - of the nationalist identity politics.

The negative side of the fantasy is a destabilizing dimension, the elementary form of which is envy, jealousy and loathing (Žižek 1998, p. 192). This side of the fantasy consists of the collection of things that irritate $u s$ about others. Those others are threatening our being, destroying our cultural heritage, invading our harmonious communities, intruding into our existence. The nationalist fantasy that promises the stable national community requires that its inherent impossibility - its core is necessarily made of a space of void, of antagonisms and disagreements - is projected in the racist fantasy onto others who are deported from our nation. The lack is not immanent in us but merely caused by the intruding others. Fearful and hated otherness that is invented has no essential or biological features, and, as Stephen Frosh says, 'as a fantasy category, racial "otherness" can be used to mean virtually anything' (Frosh 2013, p. 150).

These intruders are, paradoxically, considered to be powerful. They must have something we do not have. They possess the full enjoyment without lack. They have an unmediated relationship with God. They enjoy the immediate promise of paradise. They have unlimited sexual prowess. They exist immediately without the mediation of the Other as language. Thus, they are not barred and divided subjects. Their excessive 
enjoyment threatens to overpower us. We wonder why they do not accept our values, laws, ideals and way of life. We worry because these others do not submit to the lacking enjoyment under the symbolic order. At the same time, we manage to enjoy as we fantasize their enjoyment without lack. Actually, this excessive fantasy is stolen from $u s$. The imputation of the excessive enjoyment to others we sense as the theft of our enjoyment. What we conceal by this imputation is 'the traumatic fact that we never possessed what was allegedly stolen from us: the lack ("castration") is originary, enjoyment constitutes itself as "stolen"” (Žižek 1993, p. 203). The foreclosed obverse of our nation and its subjects returns in the guise of our paranoiac obsession with it. The effectiveness of the destabilizing side of the fantasy is the condition for the stabilizing side of the fantasy to maintain its hold (Žižek 1998, p. 192). The two sides of the fantasy - stabilizing and destabilizing, inclusive (we) and exclusive (they) depend on each other: the nationalist fantasy can be said to be 'essentially' racist.

This racist nationalist fantasy structure functions at the core of our being, offering $u s$ and the nation nationalist subject positions that are at a distance from the void of the subject, the barred S, and the nation, the barred Other. This fantasy shapes $u s$ and is inscribed into our racist actions, discourses and prejudices at the symbolic level. The fantasy includes conscious sadistic representations, such as that 'those who do not accept our values must be excluded so that we can win back our true nation'. More fundamental is the repressed masochistic content of the fantasy through which we project our insecurities onto those others who are, at the same time, intruders who have what we have lost. We are willingly being subordinated to these aliens within us.

Hence, the racist nationalist fantasy is objectively subjective, 'the way things actually, objectively seem to you even if they don't seem that way to you', as Daniel C. Dennet puts it (Žižek 2006, p. 52). What 'we don't know that we know' are 
disavowed beliefs, prejudices and presumptions we have without knowing (Žižek 2006, p. 52). The mother, telling the child that that the black man is no threat, may actually be a racist. Considering herself a liberal humanist, she just does not know that her racist prejudices determine her acts, views and emotions. This is why racism may be an elemental part of not only the far-right anti-immigration nationalist identity politics but also the liberal-democratic (and non-xenophobic right-wing populist) version of this identity politics. The fantasy functions even if it is inaccessible to the divided subject divided since she/he is not able to fully know and assume the fantasy kernel of its being. There is a gap between the imaginary-symbolic integration and the fantasy, even though all these three, (the imaginary, symbolic and fantasy), are involved in the trajectory that ends with the identification with one true nation and race. There is a gap between our anti-immigration policies and the racist nationalist fantasy that supports it as its background. The racist, who wishes to take stolen enjoyment back, does not know or consciously admit how much 'the "racial other" is actually needed, envied, desired' (Hook 2008, p. 146). As this sadistic and masochistic fantasy crosses into reality, it gives a key to our destiny and our politics of fear. Racism is, at this level, the permanent acting out of this fantasy.

\section{RACISM AND LACK}

The invention of objects of fear is related to the avoidance of anxiety. For Lacan, anxiety is not related to the ego and its response to the castration or a loss in general. Unlike Freud, Lacan considers anxiety not without an object. Lacan does not say that anxiety has an object but that it is not without. Anxiety has 'a different sort of object from the object whose perception is prepared and structured' (Lacan 2014, p. 76). At the level of the symbolic, 'Signifiers turn the world into a network of traces in which 
the transition from one cycle to another is thenceforth possible' (Lacan 2014, p. 76). The constitutional lack or the cut makes the presence and function of signifiers possible and the subject a desiring being. Object $a$ is not the object of desire but the object of drive and the object cause of desire, which instead of having objects is constantly seeking missing objects. It itself is not any partial object, such as the breast, feces, the gaze or the voice, which are merely semblances for object $a$. Object $a$ represents not an object that the subject lacks but is the lack itself. If this object cause of desire is lost, that is, if there is a full enjoyment, desire vanishes.

Anxiety arises when the lack is lacking. The object of anxiety is this peculiar object $a$. The lack of lack is not simply the refusal of castration. Freud's Unheimitiche, the non-familiar or uncanny, the sudden irruption of something that should have remained hidden, is decisive. Something appears where there should be lack. The excessive maternal presence that does not leave any room for its lack is anxietyprovoking. The mother appears as the Thing without the name of the father that would introduce a cut and a distance between the mother and the infant. The Other requires that the subject hands her-/himself over unconditionally to the total enjoyment of the Other that the subject presumes. The place of this presumed enjoyment is the place of the Thing, das Ding. 'The reverse of the object $a$, when the borders that it tries to cover are erased, is the hidden opposite side, that is, das Ding' (Harari 2001, p. 74, see pp. 58-86). Thus, anxiety is an affect caused by becoming too close to the real.

The fantasy is a device that attempts to deal with this overly close proximity with the uncanny real, thus functioning as a defencse against anxiety. The fantasy is like a bottle cap protecting the subject from the encounter with the real. It guarantees the subject a veil for the lack. Object $a$ is the bottle cap of the fantasy. As such it must be considered from two sides. On the one hand, object $a$ occupies the mouth of the 
bottle. It produces the hole and is the mouth, the gap, the void. On the other hand, it blocks this mouth, covers the void and hole in the symbolic order. At the same time, object $a$ masks the lack and preserves it. 'It is the void caused by the lack that keeps the phantasy in its place' (Harari 2001, p. 60, see pp. 58-62). The fantasy that supports the everyday reality and subjectifies the real is the subject's relationship with object $a$.

The racist nationalist fantasy tells $u s$ that the constitutive lack of the desiring subject is not constitutive but a loss due to theft. If anxiety is aroused when the lack comes to lack, in the fantasy the lack comes to be filled by our pure national being. Inventing a fantasy of the other who has what is stolen from $u s$ - that is, the loss of enjoyment as castration - we can cling to the idea of the full identity and unmediated unity in a total community that will guarantee our excessive enjoyment. Instead of the constitutive lack, we have merely lost something that can be found again. The only thing we have to do is to take enjoyment back from those who have stolen it from $u s$. Therefore, we invent those others as the objects of fear at the fantasy level. The object that provokes nervousness or anxiety cannot be located, but one eagerly seeks some object to reach the order of fear. According to Harari, when the transformation takes place, 'The object of reference can then be rationalized as belonging to the "external" world', which brings a certain degree of relief, given that there are means to avoid the object or circumscribe the threatening focus (Harari 2001, p. 32). As the girl manages

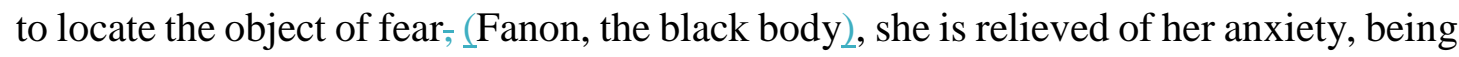
protected at the same time from this object by her mother. However, this is not truly the object of fear but an object that is there for the simple purpose of being a screen on which the girl can project her anxiety. Her anxiety projected onto the other returns as a fear from which she is relieved when Fanon disappears from her sight. 
The racist nationalist fantasy producing external objects of fear is a device to avoid anxiety. Five points are significant here.- 1 . Our anxiety is related to object $a$, to the lack in the symbolic order and the semblance that veils it. We make the total nation, a semblance of object $a$, present through the invention of a fantasy stage where it appears. Our fantasy covers fundamental antagonisms, constitutional fissures, insecurities and the lack of individual and national identity which causes anxiety. 2 . The excessive enjoyment, the lack of lack, also causes anxiety. The fantasy deals with this by transferring the excessive enjoyment onto others. They have access to the full and consistent enjoyment. They have the object $a$ that we do not have. These others present the position of enjoyment for $u s$ as long as we are detached from them. 3. At the same time, we are able to transfer the cause of fragmentation and incoherence in the core of $u s$ and our society outside us. We are excluded from true being and the harmonious nation because of these others. They have what we have lost because they have stolen it. 4. This gives rise to pathological envy, fear and loathing. Our anxiety now has concrete objects that we have invented. These external threats can be managed by effective policies, institutions and practices. As a consequence, the racist nationalist fantasy nourishes the permanent state of exception, makes the security principle and exceptional powers as absolute necessities. Already, Hobbes saw that 'Aversion with the opinion of Hurt from the object, FEAR' is politically preferable to anxiety (Hobbes 1996, p. 41; Sokoloff 2001). 5. These objects of fear have a double function. On the one hand, they function for $u s$ as a promise of full enjoyment and identity. On the other hand, they are threatening our being and nation. As soon as we deport and banish them, we are able to both reach our true being and save ourselves from the threat of these objects of fear. We find enjoyment and identity returning to $u s$ as the envied and threatening others are excluded, even though the deported Muslim migrant remains at 
the core of our identity and within us. Even if we understand that we do not attain our satisfactory goal - the total nation, the access - we will not stop finding satisfaction elsewhere, from the exclusion of those others. It is the drive that sustains itself by this satisfaction without reaching the goal (c.f. Zupančič 2000, p. 242).

All in all, this racist nationalist fantasy frames an acceptable reality for us. It has material, imaginary and symbolic effects as it structures the racist nationalist reality. It captures $u s$, and we are able to be convinced of our nation and our national, racial and ethnic identity as long as this fantasy is active and functions. The fantasy - in which our 'identity emerges as a defensive reaction to what threatens it' (Žižek 2015a) supports our identification with the racist nationalist signifiers and the agenda of the nationalist identity politics. This politics could be considered, ultimately, as the nationalist and racist politics of fantasy. This is the background that fuels and corroborates the new normality, that is, the state of exception.

\section{CONCLUSION: ANTI-RACIST POLITICS}

New walls are being built around the world. Those others of the racist nationalist images, discourses and fantasies are forced to live on the other side of these walls. According to Žižek: 'more and more they live in another world, in a blank zone that offers itself as a screen for the projection of our fears, anxieties and secret desires. The "subject supposed to loot and rape" is on the other side of the wall' (Žižek 2008, p. 88). The pathological invention of the objects of fear is developing conditions which lead to the nationalist walls of nationalist hatred and racism.

Racist imaginary, nationalist signifiers and xenophobic discourses create vicious circles of hate and give justification for the nationalist identity politics of fear, legitimize the repression of the labelled objects, justifies crisis management as the 
necessary form of depoliticized governance, and raise security as the organizing principle of the social-symbolic order. To counter this politics of fear, these racist nationalist images and discourses must be recognized, analyzed, deconstructed and opposed

However, this is an inadequate response, as I hope to have shown, to racism and intolerance. 'What, Freud effectively asks, could be more political than the fantasy when it determines the fate of entire communities, nations, and even continents?' (Lane 1998, p. 7). Without addressing the racist nationalist fantasy, the discourse and politics of fear cannot be interrupted and the nationalist identity politics - that gives support and justification for the hegemony of the security principle and the permanent state of exception praised both by the far-right populists and liberal-democrats - cannot be fought against effectively.

There are three possible positions for anti-racist emancipatory politics in relation to the fantasy.

First, the politics of traversing the fantasy, la traverse du fantasme. The ethical task for Lacan is 'the true awakening not only from sleep, but from the spell of fantasy that controls us even more when we are awake' (Žižek 2006, p. 60). The ultimate aim of the analyst 'is to deprive the subject of the very fundamental fantasy that regulates the universe of his (self-)experience' (Žižek 2006, p. 53).

This fantasy is not merely the ego's imaginary construction but something that concerns the destiny and position in reality of the racist subject. The fantasy is the cause of racists that, on the one hand, determines their identity and being and, on the other hand, answers the question of what the nation wants from them. The more it is demanded of them by rational arguments that they renounce the fantasy, the more they cling to it since it is what they are. Racists have nothing more to give than this fantasy 
and the invented paranoid objects. Therefore, it is not enough that racists understand and speak of their fantasy. Instead, going beyond the fantasy has to take place inside this fantasy. The desire must traverse this fantasy that supports the desire of racists.

The traversing of the fantasy would mean that the racist subject accepts that there is no secret treasure of total national unity which would guarantee the identity and enjoyment of the subject without lack. Racists confront the empty frame of nationalism as nothing but framed emptiness. This results not in a position without any fantasy but in altering racists' position in relation to object $a$. Racists may identify themselves not with object $a$ as the screen or promise of full being, as the object of desire, but with the lack, with object $a$ as the object cause of desire. The racist subject identifies with her/his subjective position in relation to the fantasy (McMillan 2012, pp. 72-75). Thus, we are interrupted.

Second, the anti-racist politics that struggles against racist images and anchoring points should also fight against the racist nationalist fantasy which supports racists' actions, attitudes and choices, and the nationalist identity politics, even if the racist does not consciously know that. To have any effect on racists' relation to their fantasy, egalitarian politics has to have access to the fantasy material and deprive the racists of that material. Politics should fight against the fidelity to the racist nationalist fantasy by bringing forth the constitutive lack beyond the reality of the screen of this fantasy. Instead of merely explaining this fantasy away as a pathological and illusionary formation, its function and material content ought to be interrupted and dislocated.

What anti-racist politics brings forth is the fact that there is lack in the symbolic Other, that the total homogenous nation is merely a semblance that positivizes and fills the constitutive lack. If the nationalist identity politics imagines enemies and threats, the total presence of identity and the possibility of full enjoyment, emancipatory politics 
should start from the lack of any stable identity. The borders of bodies and nations are inevitably porous. Beyond the pathological fantasy structure, the discourse of fear and the nationalist identity politics faces nothing but the constitutive lack. The nationalist identity politics fails as its racist fantasy support breaks down.

The fact that the individual and national identity are lacking and the subject is divided beyond return to any alleged consistency opens a space for politics beyond the nationalist identity politics. Politics as disagreements takes place around the lack which should be considered a constitutive gap and not a stolen property. Emancipatory politics has the courage to touch the Real and confront the fundamental asymmetry in the symbolic order. Politics that is not reduced to the identity politics is the politics of impossibility. The traversing of the fantasy is accepting the fundamental and constitutive lack in the core of individual and national being. It means the affirmation of the pending political, social and economic antagonistic dissensus. The nation is irrevocably symbolically castrated. Politics turns around the object $a$ designating the absence of harmonious totality. Lacan's 'That's not it' is the precondition of any politics (Lacan 1999, p. 126). It is the political answer to all those who claim to offer the satisfaction of enjoyment or the fulfillment of national existence. Politics is refusing this, 'because that's not it'. The only space of politics is 'a place that is "occupied by the lack"” (Zupančič 2000, p. 242).

Third, what about egalitarian fantasies? As democratic politics disagrees with pathological subjective and national positions based on the racist nationalist fantasy, the political subject must invent her/his own privileged signifiers - equality, emancipation, solidarity - around which emancipatory politics is constructed. One could continue by saying that all fantasmatic objects should be removed from politics, the sphere of which is the symbolic order. But if the traversing of the fantasy means not 
getting rid of fantasies but adopting a new position in relation to the fantasy, then one could also consider the nature of these fantasies in which the subject has a subjective position. Perhaps politics has to invent its own fantasies involving the tradition of emancipatory-egalitarian struggles and indicating unseen possibilities that are considered impossible: for example, communism as the equality of existences in this shared world, as freedom 'freed from its non-egalitarian submission to property' (Badiou 2013, p. 46). This dissensual fantasy would raise the impotence and castration to impossibility by affirming and being committed to a semblance of object $a$ that both racist nationalists and liberal democrats consider impossible and unattainable. Then again, communism is not 'just' a fantasy, even though it lacks appropriate signifiers for its egalitarian possible impossibility. The fantasy would fill the gap between the communist hypothesis and its signifiers (c.f. Žižek 2015a).

What this interrupting, committed and inventive politics, in practice, would be is beyond the scope of this text. Or rather, a radical emancipatory politics cannot ever be imagined, programmed or fantasized without losing its potentialities. It takes place, if it has its anti-racist events of equality.

\section{BIBLIOGRAPHY}

Agamben, Giorgio. 2001. Security and terror, trans. Carolin Emcke. Theory and Event 5(4). https://muse.jhu.edu/article/32641. Accessed 24 July 2017.

Altheide, David L. 2006. Terrorism and the politics of fear. Cultural Studies - Critical Methodologies 6(4): 415-439.

Anderson, Benedict. 1993. Imagined communities: Reflections on the origin and spread of nationalism. London: Verso.

Badiou, Alain. 2008. The meaning of Sarkozy, trans. David Fernbach. London: Verso. 
Badiou, Alain. 2012. Le racism des intellectuels. Le Monde, 5 May 2012. http://www.lemonde.fr/election-presidentielle-2012/article/2012/05/05/le-

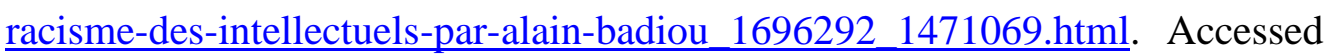
24 July 2017.

Badiou, Alain. 2013. Our contemporary impotence, trans. Olivia Lucca Fraser. Radical Philosophy 181: 43-47.

Badiou, Alain. 2015. Eleven points inspired by the situation in Greece. Verso Blog, 9 July 2015. https://www.versobooks.com/blogs/2111-alain-badiou-elevenpoints-inspired-by-the-situation-in-greece. Accessed 24 July 2017.

Balibar, Etienne and Immanuel Wallerstein. 1988. Race, nation, classe: les identités ambiguës. Paris: La Découverte.

Bamat, Joseph. 2017. France's Macron 'to end state of emergency', but keep its antiterror powers. France24, 9 June 2017. http://www.france24.com/en/20170609france-state-emergency-macron-police-powers-civil-liberties-terrorism. Accessed 24 July 2017.

Chrisafis, Angelique, and Larry Elliott, Jill Treanor. 2016. French PM Manuel Valls says refugee crisis is destabilising Europe. The Guardian, 22 January 2016. https://www.theguardian.com/world/2016/jan/22/french-pm-manuel-vallssays-refugee-crisis-is-destabilising-europe. Accessed 24 July 2017.

Clarke, Simon. 2003. Social theory, psychoanalysis and racism. Houndmills: Palgrave. Dearden, Lizzie. 2017. French human rights 'at tipping point' as state of emergency continues, says Amnesty International. Independent, 23 February 2017. http://www.independent.co.uk/news/world/europe/france-state-of-emergencyextended-latest-human-rights-law-isis-amnesty-international-reporta7595251.html. Accessed 24 July 2017. 
Devetak, Richard. 2004. In fear of refugees: The politics of border protection in Australia. International Journal of Human Rights 8(1): 101-109.

Dolar, Mladen. 1999. Where does power come from? New Formations 35: 7992.

Fanon, Franz. 1986. Black skin, white mask, trans. Charles Lam Markmann. London: Pluto Press.

Freud, Sigmund. 1920. A general introduction to psychoanalysis, trans. G. Stanley Hall. New York: Horace Liveright. http://www.gutenberg.org/ebooks/38219. Accessed 24 July 2017.

Frosh, Stephen. 2013. Psychoanalysis, colonialism, racism. Journal of Theoretical and Philosophical Psychology 33(3) : 141-154.

Harari, Roberto. 2001. Lacan's seminar on 'anxiety'. An introduction. New York: Other Press, ix-lxii.

Hobbes, Thomas. 1996. Leviathan. Cambridge: Cambridge University Press.

Hook, Derek. 2007. Pre-discursive racism. LSE Research Online. http://eprints.lse.ac.uk/arvhive/00000957. Accessed 24 July 2017.

Hook, Derek. 2008. The 'real' of racializing embodiment, Journal of Community and Applied Social Psychology 18(2): 140-152.

Hörnqvist, Magnus. 2004. The birth of public order policy. Race and Class 46(1): 3052.

Oliver, Kelly. 2001. Witnessing beyond recognition. Minneapolis \& London: University of Minnesota Press.

Kuper, Simon. 2017. Macron, Le Pen and the battle for the idea of France. Financial Times 6 May 2017.

Lacan, Jacques. 1966-67. La logique du fantasma. Le Séminaire. Livre XIV. (Unpublished). 
Lacan, Jacques. 1999. Encore. The seminar of Jacques Lacan. Book XX, trans. Bruce Fink. New York: Norton.

Lacan, Jacques. 2004. The four fundamental concepts of psychoanalysis: The seminar of Jacques Lacan. Book XI, trans. Alan Sheridan. London: Karnac.

Lacan, Jacques. 2006a. The mirror stage as formative of the $I$ function. In Ecrits, trans Bruce Fink. New York: W.W. Norton \& Company, 75-81.

Lacan, Jacques. 2006b. The subversion of the subject and the dialectic of desire. In Ecrits, trans. Bruce Fink. New York: W. W. Norton \& Company, 671-702.

Lacan, Jacques. 2014. Anxiety. The seminar of Jacques Lacan. Book X, trans. A.R. Price. Cambridge: Polity.

Lane, Christopher. 1998. The psychoanalysis of race. New York: Columbia University Press.

May, Todd. 2010. Contemporary political movements and the thought of Jacques Rancière. Equality in Action. Edinburgh: Edinburgh University Press.

McMillan, Chris. 2012. Žižek and communist strategy. On the disavowed foundations of global capitalism. Edinburgh: Edinburgh University Press.

Rancière, Jacques. 1999. Disagreement. Politics and philosophy, trans. Julie Rose. Minneapolis, MN \& London: University of Minnesota Press.

Rancière, Jacques. 2004. Introducing disagreement. Angelaki, Journal of the Theoretical Humanities 9(3): 3-9.

Rancière, Jacques. 2006. Our police order: What can be said, seen, and done. Interview with Truis Lie. Le Monde diplomatique, 8. http://www.eurozine.com. Accessed 24 July 2017.

Rancière, Jacques. 2009. Aesthetics and its discontents, trans. Steven Corcoran. Cambridge \& Malden, MA: Polity. 
Rancière, Jacques. 2013. A precarious dialogue. Maria Kakogianni and Jacques Rancière, trans. Olivia Lucca Fraser. Radical Philosophy 181: 18-25.

Rancière, Jacques. 2015. Les idéaux républicains sont devenus des armes de discrimination et de mépris. Interview with Eric Aeschimann. L'Obs, 4 April 2015.

Sokoloff, William W. 2001. Politics and Anxiety in Thomas Hobbes's Leviathan. Theory \& Event 5(1): 1-14. https//muse.jhu.edu/article/32618.

Stavrakakis, Yannis. 2013. Debt society. Greece and the future of post-democracy. Radical Philosophy 181 (Sept/Oct): 33-39.

Verhaeghe, Paul. 2014. What about Me? The Struggle for Identity in a Market-based Society, trans. Jane Hedley-Prôle. Brunswick, Victoria: Scribe.

Winnubst, Shannon. 2004. Is the Mirror Racist? Interpreting the Space of Whiteness. Philosophy and Social Criticism 30(1), 25-50.

Žižek, Slavoj. 1993. Tarrying with the negative. Durham: Duke University Press.

Žižek, Slavoj. 1998. The seven veils of fantasy. In Key concepts of Lacanian psychoanalysis, ed. Dany Nobus, 190-218. New York: Other Press.

Žižek, Slavoj. 2004. What does Europe want? In these times 1 May 2004. http://inthesetimes.com/article/166. Accessed 24 July 2017.

Žižek, Slavoj. 2006. Lacan. London: Granta Books.

Žižek, Slavoj. 2008. Violence. Six sideways reflections. London: Profile Books.

Žižek, Slavoj. 2012. Save us from the saviours. London Review of Books 7 June 2012. https://www.lrb.co.uk/v34/n11/slavoj-zizek/save-us-from-the-saviours. Accessed 24 July 2017. 
Žižek, Slavoj. 2016. Migrants, racists and the left. Spiked Review May 2016. http://www.spiked-online.com/spiked-review/article/migrants-racists-and-theleft/18395\#.WV9cGGeKTdM. Accessed 24 July 2017.

Žižek, Slavoj. 2015a. The need to traverse the fantasy. In these times. $\underline{\text { http://inthesetimes.com/article/18722/Slavoj-Zizek-on-Syria-refugees- }}$ Eurocentrism-Western-Values-Lacan-Islam. Accessed 24 July 2017.

Žižek, Slavoj. 2015b. The non-existence of Norway. London Review of Books, 9 September 2015. http://www.lrb.co.uk/2015/09/09/slavoj-zizek/the-nonexistence-of-norway. Accessed 24 July 2017.

Zupančič, Alenka. 2000. Ethics of the real. Kant, Lacan. London: Verso. 